\title{
TGF $\beta$-signaling in squamous cell carcinoma occurring in recessive dystrophic epidermolysis bullosa
}

\author{
Julia Knaup ${ }^{\mathrm{a}}$, Christina Gruber ${ }^{\mathrm{b}}$, Barbara Krammer ${ }^{\mathrm{a}}$, Verena Ziegler ${ }^{\mathrm{a}}$, Johann Bauer ${ }^{\mathrm{b}}$ and \\ Thomas Verwanger ${ }^{\mathrm{a}, *}$ \\ ${ }^{a}$ Department of Molecular Biology, University of Salzburg, Salzburg, Austria \\ ${ }^{\mathrm{b}}$ Division of Molecular Dermatology and EB House Austria, Department of Dermatology, Paracelsus Medical \\ University, Salzburg, Austria
}

Received: May 18, 2011

Accepted: September 30, 2011

\begin{abstract}
Background: Recessive dystrophic epidermolysis bullosa (RDEB) is a hereditary skin disorder characterized by mechanical fragility of the skin, resulting in blistering and chronic wounds. The causative mutations lie in the COL7A1 gene. Patients suffering from RDEB have a high risk to develop aggressive, rapidly metastasizing squamous cell carcinomas (SCCs). Cutaneous RDEB SCCs develop preferentially in long-term skin wounds or cutaneous scars. Albeit being well differentiated, they show a more aggressive behavior than UV-induced SCCs. These findings suggest other contributing factors in SCC tumorigenesis in RDEB.

Objective: To analyze factors contributing to RDEB tumorigenesis, we conducted a comprehensive gene expression study comparing a non-malignant RDEB (RDEB-CL) to a RDEB SCC cell line (SCCRDEB4) to achieve an overview on the changes of the gene expression levels in RDEB related skin cancer.

Methods: We applied cDNA arrays comprising 9738 human expressed sequence tags (EST) with various functions. Selected results were verified by Real-time RT PCR.

Results: Large-scale gene expression analysis revealed changes in the expression level of transforming growth factor $\beta 1$ (TGF $\beta 1$ ) and several genes under the control of TGF $\beta$ for RDEB and SCCRDEB4 cell lines. Even the untransformed RDEB keratinocytes show elevated levels of TGF $\beta 1$.

Conclusion: Our findings demonstrate a prominent role of TGF $\beta$-signaling in RDEB-related skin cancer. Once activated, TGF $\beta$ signaling either in response to wounding or in order to influence type VII collagen expression levels could facilitate cancer development and progression. Moreover, TGF $\beta$ signaling might also represent a potentially useful therapeutic target in this disease.
\end{abstract}

Keywords: Recessive dystrophic epidermolysis bullosa, squamous cell carcinoma, gene expression, cDNA array, real-time PCR, TGF $\beta$-signaling

\section{List of abbreviations}

CDHE E-Cadherin

EMT Epithelial-mesenchymal transition

EST Expressed sequence tag

*Corresponding author: Thomas Verwanger, Department of Molecular Biology, University of Salzburg, Hellbrunnerstrasse 34, 5020 Salzburg, Austria. E-mail: thomas.verwanger@sbg.ac.at.
FN Fibronectin

GAPDH Glyceraldehyde-3-phosphotase dehydrogenase

GPNMB Glycoprotein nonmetastatic B

HPRT Hypoxanthine ribosyltransferase

KRT18 Keratin 18

LRP-1 Low density lipoprotein receptor-related protein 1

MMP Matrix metalloproteinase 


\begin{tabular}{|c|c|}
\hline RDEB-CL & $\begin{array}{l}\text { Non-malignant RDEB } \\
\text { keratinocyte cell line }\end{array}$ \\
\hline RDEB-O & Other generalized RDEB \\
\hline RDEB & $\begin{array}{l}\text { Recessive dystrophic } \\
\text { epidermolysis bullosa }\end{array}$ \\
\hline $\mathrm{SSC}$ & Saline-sodium citrate \\
\hline SCCRDEB4 & SCC RDEB keratinocyte cell line \\
\hline SPARC & $\begin{array}{l}\text { Secreted protein acidic and rich in } \\
\text { cysteine }\end{array}$ \\
\hline RDEB-sev gen & Severe generalized RDEB \\
\hline SDS & Sodium dodecyl sulfate \\
\hline SCC & Squamous cell carcinoma \\
\hline TSP-1 & Thrombospondin-1 \\
\hline TIMP-1 & $\begin{array}{l}\text { Tissue inhibitor of matrix } \\
\text { metalloproteinases }\end{array}$ \\
\hline TGF $\beta 1$ & Transforming growth factor $\beta 1$ \\
\hline TRIM27 & $\begin{array}{l}\text { Tripartite motif-containing } \\
\text { protein } 27\end{array}$ \\
\hline COL1A2 & Type I collagen \\
\hline COL7A1 & Type VII collagen \\
\hline VCL & Vinculin \\
\hline
\end{tabular}

\section{Introduction}

Recessive dystrophic epidermolysis bullosa (RDEB) is a mechano-bullous hereditary skin disorder characterized by extreme skin fragility. Even minor mechanical traumata result in massive blistering of the skin and slowly or non-healing wounds [17]. There are two major subtypes of RDEB: severe generalized RDEB (RDEB-sev gen; previously termed "Hallopeau-Siemens" subtype) and other generalized RDEB (RDEB-O) [36] which differ in clinical severity. Genetic analysis revealed that the causative mutations lie in the COL7A1 gene. This gene encodes for type VII collagen which is known to be the major component of the anchoring fibrils that connect the epidermis to the dermis $[54,110]$. In less severe cases mutations result in reduced levels of type VII collagen, while in RDEB-sev gen no or very low levels of type VII collagen (COL7A1) are observed [113]. Apart from blistering, subsequent injury of the whole skin surface (also mucosae can be involved) and mutilating scars [87], RDEB can further be complicated by growth retardation, anemia, pseudosyndactyly and corneal erosions [36]. Patients suffering from RDEB also have a high risk to develop aggressive, rapidly metastasizing squamous cell carcinomas (SCCs) [82,
130] even in early adulthood [65]. This risk increases dramatically with age. Statistical analysis revealed that nearly all patients suffering from RDEB-sev gen develop at least one SCC throughout life and about $80 \%$ perish within the following five years of diagnosis [37]. As seen in other chronic, severe scarring conditions after thermal burns, the SCCs generally develop within long-term skin wounds or cutaneous scars [37]. This is in contradiction to UVinduced SCCs, which tend to develop at sun exposed areas [5]. Although RDEB-related SCC appear to be well differentiated, they exhibit highly aggressive behavior which is not indicated for normal SCCs [35]. These findings suggest other contributing factors in SCC tumorigenesis [37]. Several studies focused on the underlying mechanisms of RDEB-related SCC and the comparison of those SCC to UV-induced SCC. Unfortunately, they have not yielded a greater comprehension into carcinogenesis in RDEB and only few peculiarities in RDEB SCC gene expression were revealed. The differences between carcinogenesis of RDEB and normal skin are currently being investigated [35].

This study aims at the elucidation of factors contributing to aggressiveness of SCC in the context of RDEB. A comparative study of comprehensive gene expression profiles of both normal and malignant RDEB keratinocytes should reveal changes in gene expression. Those changes were further evaluated for their contribution to high morbidity rates in RDEB cancer. Here, we focus on expression changes in transforming growth factor $\beta 1$ (TGF $\beta 1$ ) and some related genes.

\section{Material and methods}

\subsection{Cell lines and RNA samples}

SCCRDEB4 [129] cells were kindly provided by Dr. Andrew South, Dundee, UK and RDEB-CL cells were obtained from Prof. Guerrino Meneguzzi, Nice,

Table 1

Cell lines, RDEB subtype and mutations

\begin{tabular}{lcl}
\hline Cell line & RDEB subtype & Mutation \\
\hline RDEB-CL & RDEB-sev gen & COL7A1(7786delG/R578X) \\
SCCRDEB4 & RDEB-sev gen & COL7A1 (8244dupC/8244dupC) \\
HaCaT & - & Wild type \\
\hline
\end{tabular}


France. As control for both RDEB cell lines served $\mathrm{HaCaT}$ cells. All cell lines were routinly grown in Keratinocyte-SFM, supplemented with bovine pituitary extract and recombinant epidermal growth factor (Invitrogen, USA) (Table 1).

\subsection{Probe synthesis}

RNA isolation and cDNA labelling was done essentially as described by Aberger et al. [1]. Briefly, after harvesting cells were lysed using Tri Reagent ${ }^{\mathrm{TM}}$ (MRC Inc., USA) and RNA was isolated using the provided protocol. Labelling of cDNA to high specific activity by reverse transcription was carried out by using $15 \mu \mathrm{g}$ total RNA, $70 \mu \mathrm{Ci} \cdot{ }^{33} \mathrm{P}-\mathrm{dCTP}(3000 \mathrm{Ci} / \mathrm{mmol}$, Amersham Biosciences, USA), $10 \mu \mathrm{l} 3 \times$ labelling buffer (for $200: 120 \mu 15 \times$ SuperScript $^{\mathrm{TM}}$ reverse transcriptase buffer (Invitrogen, USA), $3 \mu \mathrm{l}$ dAT/dGTP/dTTP $100 \mathrm{mM}$ each, $60 \mu \mathrm{l} 0.1 \mathrm{M}$ DTT, $0.8 \mu \mathrm{l} 1 \mathrm{mM}$ dCTP, $10.2 \mu \mathrm{l}$ DEPC treated ddH2O) and $2 \mu \mathrm{l}$ SuperScript II reverse transcriptase (Invitrogen). The labelled probes were subsequently purified using GFX columns (Amersham) according to the manufacturer's protocol.

To measure and verify the incorporation and quality of the labeling reaction, scintillation-counting was performed.

\subsection{Array hybridization and data analysis}

Nitrocellulose membranes of $22 \times 22 \mathrm{~cm}$ (Hybond $\mathrm{N}+$, Amersham Biosciences, UK) were spotted with PCR products of 9738 ESTs of the Incyte Human UniGEM Microarray clone set in duplicates on a MicroGrid II arrayer (BioRobotics, UK). Prehybridization was carried out for $2 \mathrm{~h}$ at $65^{\circ} \mathrm{C}$. cDNA probes were denatured for $5 \mathrm{~min}$ at $95^{\circ} \mathrm{C}$. Then the filters were hybridized with labeled cDNAs for 2 days at $65^{\circ} \mathrm{C}$ in pre-warmed hybridization buffer $(5 \mathrm{X}$ Denhardt's solution, $5 \mathrm{X}$ saline-sodium citrate (SSC), $1 \%$ sodium dodecyl sulfate (SDS)). Afterwards the filters were washed four times in buffers with declining SSC concentration $\left(20\right.$ minutes and $65^{\circ} \mathrm{C}$ each): $2 \times \mathrm{SSC} / 0.1 \% \mathrm{SDS}, 0.2 \times \mathrm{SSC} / 0.1 \% \mathrm{SDS}$ (carried out twice) and $0.1 \times \mathrm{SSC} / 0.1 \%$ SDS. Subsequently, filters were rinsed in $2 \times \mathrm{SSC}$, sealed in Saran-wrap and exposed four days to phosphorimager screens (Fuji, Germany). These screens were scanned using BAS READER 1800 II phosporimager (Fuji, Germany). For each RNA sample two arrays were hybridized, so four hybridization spots per EST could be used for statistical analysis.

\subsection{Image and data analysis}

After spot intensity calculation using AIDA software (Raytest, Germany), data was exported to Microsoft Excel (Microsoft, USA). Each spot signal was normalized for total signal intensity of all spots on the array.

\subsection{Real-time RT-PCR}

Genes of interest (see Table 2) which showed strong up- or down-regulation exceeding a factor of 1.8 were chosen for verification using real-time RT PCR. Primers were designed using the open-source primer design software PerlPrimer [78] and ordered at Sigma Aldrich (see Table 2).

For PCR reaction True-Start ${ }^{\mathrm{TM}}$ Hot Start Polymerase (MBI Fermentas, Germany) was used. The annealing temperature for each primer pair was determined using melting curves and 2\% agarose gel banding of PCR products. The expression of three housekeeping genes was monitored (see Results) for normalization. The results of each PCR reaction were calculated using the Bio-Rad 'Genex' MS-Excel macro (Gene Expression Analysis for iCycler $\mathrm{iQ}^{\circledR}$ Real-Time PCR Detection System) based on the algorithms outlined by Vandesompele et al. [127].

\section{Results}

Genes of interest (Table 2) chosen from the array results were those which play a role in the TGF $\beta$ signaling. Additionally they exceed a factor of 1.8 for up- or down-regulation compared to the reference. The $\mathrm{HaCaT}$ cell line served as reference for both RDEB cell lines. The results of real-time RT-PCR analysis are listed in Table 3. RDEB cells show significant over-expression of TGF $\beta 1$, TIMP-1 (tissue inhibitor of matrix metalloproteinases-1), CDHE (E-cadherin), FN1 (fibronectin 1), COL7A1 and COL1A2 (type I collagen), and significant under-expression of LRP1 (low density lipoprotein receptor-related protein 1) and VCL (vinculin). 
Table 2

Selected genes and primers

\begin{tabular}{|c|c|c|c|c|}
\hline Gene & Abbre-viation & RefSeq ID & Forward primer $\left(5^{\prime}-3^{\prime}\right)$ & Reverse primer $\left(5^{\prime}-3^{\prime}\right)$ \\
\hline $\begin{array}{l}\text { Glyceraldehyde-3- } \\
\text { phosphotase } \\
\text { dehydrogenase }\end{array}$ & GAPDH & NM_002046 & $\begin{array}{l}\text { GTGAAGGTCGGAGTCAA } \\
\text { CG }\end{array}$ & $\begin{array}{l}\text { TGAGGTCAATGAAGGGG } \\
\text { TC }\end{array}$ \\
\hline $\begin{array}{l}\text { Hypoxanthine } \\
\text { ribosyltransferase }\end{array}$ & HPRT & NM_000194 & $\begin{array}{l}\text { GGGCTATAAATTCTTTGC } \\
\text { TGAC }\end{array}$ & $\begin{array}{l}\text { CTGGTCATTACAATAGC } \\
\text { TCTTCAG }\end{array}$ \\
\hline $\begin{array}{l}\text { Tripartite motif-containing } \\
\text { protein } 27\end{array}$ & TRIM27 & NM_030950 & $\begin{array}{l}\text { CAGGCACGAGCTGAACT } \\
\text { CT }\end{array}$ & $\begin{array}{l}\text { AGCTGCTCAAACTCCCA } \\
\text { AAC }\end{array}$ \\
\hline $\begin{array}{l}\text { Transforming growth factor } \\
\text { beta }\end{array}$ & TGF $\beta 1$ & NM_000660 & $\begin{array}{l}\text { AACCCACAACGAAATCT } \\
\text { ATGAC }\end{array}$ & $\begin{array}{l}\text { TAACTTGAGCCTCAGCA } \\
\text { GAC }\end{array}$ \\
\hline $\begin{array}{l}\text { TIMP metallopeptidase } \\
\text { inhibitor } 1\end{array}$ & TIMP-1 & NM_003254 & $\begin{array}{l}\text { GTCCCTGCGGTCCCAGAT } \\
\text { A }\end{array}$ & $\begin{array}{l}\text { GTGGGAACAGGGTGGAC } \\
\text { ACT }\end{array}$ \\
\hline E-cadherin & CDHE & NM_004360 & $\begin{array}{l}\text { AAGAGGACCAGGACTTT } \\
\text { GAC }\end{array}$ & $\begin{array}{l}\text { CACGAGCAGAGAATCAT } \\
\text { AAGG }\end{array}$ \\
\hline Thrombospondin-1 & TSP-1 & NM_003246 & $\begin{array}{l}\text { CGACCAGAAGGACTCTG } \\
\text { ACGGCGAT }\end{array}$ & $\begin{array}{l}\text { GGACGAGTTCTTTACCC } \\
\text { TGATGGCG }\end{array}$ \\
\hline $\begin{array}{l}\text { Low density lipo-protein } \\
\text { receptor-related protein } 1\end{array}$ & LRP1 & NM_002332 & $\begin{array}{l}\text { GCCTGCAGAGATCAAAT } \\
\text { AACC }\end{array}$ & $\begin{array}{l}\text { ССТTACTCTGTGGACAA } \\
\text { АTCTC }\end{array}$ \\
\hline Fibronectin 1 & FN1 & ENSG0000011541 & $\begin{array}{l}\text { ATGCCGACCAGAATTTGG } \\
\text { G }\end{array}$ & $\begin{array}{l}\text { CCCCACGACCATTCCCA } \\
\text { ACA }\end{array}$ \\
\hline Type VII collagen & COL7A1 & NM_000094 & $\begin{array}{l}\text { CTCAGCAGCTATCACCTG } \\
\text { GAC }\end{array}$ & $\begin{array}{l}\text { TGTCCACCACACGTAGT } \\
\text { TCAA }\end{array}$ \\
\hline $\begin{array}{l}\text { Secreted protein acidic and } \\
\text { rich in cysteine }\end{array}$ & SPARC & NM_003118 & $\begin{array}{l}\text { TCTTCTTTCTCСТTTGCCT } \\
\text { G }\end{array}$ & $\begin{array}{l}\text { CTCCCACAGATACCTCA } \\
\text { GTC }\end{array}$ \\
\hline $\begin{array}{l}\text { Glycoprotein nonmetastatic } \\
\text { B }\end{array}$ & GPNMB & NM_001005340 & $\begin{array}{l}\text { CGTGGTAACAGATCAG } \\
\text { ATTCCT }\end{array}$ & $\begin{array}{l}\text { AACAAACAGGCCAGTA } \\
\text { TTATCC }\end{array}$ \\
\hline Vinculin & VCL & NM_003373 & $\begin{array}{l}\text { GCCTGGGCCAGCAAGG } \\
\text { ACAC }\end{array}$ & $\begin{array}{l}\text { CCCTGGGGAGGCACTA } \\
\text { GGGT }\end{array}$ \\
\hline Type I collagen & COL1A2 & NM_000089 & $\begin{array}{l}\text { CAAGGCTGTCATTCTAC } \\
\text { AGG }\end{array}$ & $\begin{array}{l}\text { CCAAAGGTGCAATATC } \\
\text { AAGG }\end{array}$ \\
\hline Keratin 18 & KRT18 & NM_199187 & $\begin{array}{l}\text { GCGAGGACTTTAATCTT } \\
\text { GGTG }\end{array}$ & $\begin{array}{l}\text { CTCAGAACTTTGGTGTC } \\
\text { ATTGG }\end{array}$ \\
\hline
\end{tabular}

SCCRDEB4 cells show significant over-expression of TGF $\beta 1$, CDHE, SPARC (secreted protein acidic and rich in cysteine), VCL and GPNMB (glycoprotein nonmetastatic B), and significant under-expression of TSP-1 (thrombospondin-1), LRP1, FN1, COL7A1 and KRT18 (keratin 18). Especially GPNMB is massively up-regulated.

The selection of suitable housekeeping genes for real-time RT PCR analysis was somewhat challenging in the case of RDEB cells. The preliminary results of the nitrocellulose filters indicated that some of classic reference genes show abnormal expression in RDEB (e.g., actins and tubulins), arousing doubts in their usefulness as suitable housekeeping genes for the further verification of over- and under-expressed genes. Others were not included at all in the 9738 expressed sequence tags (ESTs) spotted on the filters (e.g., cyclophilin).

Structural genes like actins or tubulins were excluded as possible housekeeping genes. As RDEB is a skin disorder, chances are that structural genes are expressed differently (as indicated by the changed intensities on the nitrocellulose filters).

Therefore we chose glyceraldehyde-3-phosphotase dehydrogenase (GAPDH), hypoxanthine ribosyltransferase (HPRT) and tripartite motif-containing protein 27 (TRIM27) as housekeeping genes. These genes take part in different cellular pathways and are therefore unlikely to be co-regulated. All three showed normal expression levels according to the filter results. One is a novel housekeeping gene (TRIM27) and two are "classic" housekeeping genes (HPRT and GAPDH). 
Table 3

Real time RT-PCR results (expression ratio vs. HaCaT cells) and main functions

\begin{tabular}{|c|c|c|c|}
\hline Abbreviation & RDEB-CL (s.d.) & SCCRDEB4 (s.d.) & Main functions \\
\hline $\begin{array}{l}\text { TGF } \beta 1 \\
\quad \text { Transforming } \\
\quad \text { growth factor } \beta\end{array}$ & $2.83(0.49)$ & $4.91(1.46)$ & $\begin{array}{l}\text { - Growth-regulatory cytokine; key role in differentiation, apoptosis, matrix protein synthesis and degradation } \\
\text { [40], inflammation and angiogenesis [59] } \\
\text { - Dual role in cancer, time-dependent model: } \\
\text { early phase of tumor development } \longrightarrow \text { suppressor function } \\
\text { later stages/established tumor } \longrightarrow \text { promotes tumor cell survival, cancer progression,metastasis [59] by } \\
\text { facilitating epithelial-mesenchymal transition (EMT) [101,131], angiogenesis and escape from immune } \\
\text { surveillance [101] }\end{array}$ \\
\hline $\begin{array}{l}\text { TIMP-1 } \\
\text { Tissue inhibitor of } \\
\text { matrix metallo- } \\
\text { proteinases } 1\end{array}$ & $2.61(1.10)$ & $1.39(0.31)$ & $\begin{array}{l}\text { - TGF } \beta 1 \text { induces expression of MMP (matrix metalloproteinase) -2 and MMP-9; down-regulates inhibitors } \\
\text { TIMPs [40,59] } \\
\text { - TIMPs are the antagonists to MMPs, restrict their activation, bind to MMPs in a 1:1 stoichiometry [52] } \\
\text { - Can influence activity of growth factors [47], cell morphology [103] and inhibit angiogenesis [62] }\end{array}$ \\
\hline $\begin{array}{l}\text { CDHE } \\
\text { E-Cadherin }\end{array}$ & $2.38(0.55)$ & $6.47(1.33)$ & $\begin{array}{l}\text { - Expressed by epithelial cells (hence "E"-cadherin) } \\
\text { - Belongs to large family of cell-cell adhesion molecules [134] } \\
\text { - Part of adherens junction, plays a role in cell-cell adhesion and recognition (reviewed in [43]), spans } \\
\text { intercellular space between two cells } \\
\text { - Interacts with other proteins (e.g., VCL) coupling it to the actin cytoskeleton [93] }\end{array}$ \\
\hline $\begin{array}{l}\text { TSP-1 } \\
\text { Thrombospondin-1 }\end{array}$ & $1.41(0.31)$ & $0.14(0.03)$ & $\begin{array}{l}\text { - Involved in cell adhesion, migration, proliferation, matrix remodeling }[2,23,67,76,88,100] \text {, apoptosis [61, } \\
\text { 124], angiogenesis [112] } \\
\text { - Able to activate latent TGF } \beta 1 \text { [89] } \\
\text { - Strongly influences tumor growth, progression and metastasis } \\
\text { - Binds MMP-2 and }-9 \text { [10], enhances their cellular uptake and degradation via LRP1 }[33,46,136]\end{array}$ \\
\hline $\begin{array}{l}\text { LRP1 } \\
\text { Low density } \\
\quad \text { lipo-protein } \\
\text { receptor-related } \\
\quad \text { protein } 1\end{array}$ & $0.26(0.03)$ & $0.25(0.08)$ & $\begin{array}{l}\text { - Important for endocytosis, signal transduction [50], cell migration, proliferation, vascular permeability [72] } \\
\text { - } \longrightarrow \text { binds wide range of ligands [50, 69] (TSP-1, MMP-9, MMP-13, TGF } \beta 1[73] \text { ) } \\
\text { - } \text { LRP1 binding to TSP-1 mediates degradation of MMP-2 and MMP-9 }[84,85] \\
\text { Able to modulate TGF } \beta \text { signaling [19] }\end{array}$ \\
\hline $\begin{array}{l}\text { FN1 } \\
\text { Fibronectin }\end{array}$ & $4.55(0.72)$ & $0.22(0.06)$ & $\begin{array}{l}\text { - Ever-present matrix glycoprotein [68] } \\
\text { - Binds to various "structural" molecules (collagen, actin or fibrin [135], several integrins [4]) } \\
\text { - Functions in keratinocyte adhesion and migration }[118,122] \\
\text { - Cellular transformation causes loss of FN reducing cellular adhesion } \rightarrow \text { favorable for tumor metastasis [107] } \\
\text { - TGF } \beta \text { induces synthesis in fibroblasts and fibrosarcoma cells }[30,56,57]\end{array}$ \\
\hline $\begin{array}{l}\text { COL7A1 } \\
\text { Type VII collagen }\end{array}$ & $5.46(0.49)$ & $0.29(0.03)$ & $\begin{array}{l}\text { - TGFß1 is enhancer of type VII collagen gene expression in keratinocytes and dermal fibroblasts }[26,91,109] \\
\text { - Major component of the anchoring fibrils [54] } \\
\text { - Mutations in COL7A1 cause RDEB [54], leading to reduced or absent type VII collagen protein [113] }\end{array}$ \\
\hline
\end{tabular}

(continued next page) 
Table 3

(continued)

\begin{tabular}{|c|c|c|c|}
\hline Abbreviation & RDEB-CL (s.d.) & SCCRDEB4 (s.d.) & Main functions \\
\hline $\begin{array}{l}\text { SPARC } \\
\text { Secreted protein } \\
\text { acidic and rich in } \\
\text { cysteine }\end{array}$ & $0.90(0.21)$ & $2.59(0.56)$ & $\begin{array}{l}\text { - Matricellular protein mediating cell-matrix interactions } \\
\text { - No primarily structural role [70], expressed when changes in cell-matrix or cell-cell contact are needed [13] } \\
\text { - TGFulator of growth factor activity, cell-cycle inhibitor [70], regulator of matrix remodeling and turnover [27] } \\
\text { - is able to increase TGF } 31 \text { expression in vitro [38] }\end{array}$ \\
\hline $\begin{array}{l}\text { GPNMB } \\
\text { Glycoprotein } \\
\text { nonmetastatic B }\end{array}$ & $0.70(0.11)$ & 143.84 (31.73) & $\begin{array}{l}\text { - Transmembrane protein expressed by human keratinocytes and melanocytes [125] } \\
\text { - Able to promote TGF } \beta 1 \text { activation } \\
\text { - Able to induce MMP-3 and MMP-9 }[94,105,108]\end{array}$ \\
\hline $\begin{array}{l}\text { VCL } \\
\text { Vinculin }\end{array}$ & $0.35(0.11)$ & $6.95(1.28)$ & $\begin{array}{l}\text { - Component of focal adhesions and adherens junctions; links actin filaments to membrane [31] } \\
\text { - Ubiquitously expressed; interacts with various proteins (talin, paxillin, } \alpha \text { - and } \beta \text {-catenin) [137] } \\
\text { - Transfer of mechanical stress to the cytoskeleton, resulting in its remodeling [34] } \\
\text { - } \quad \text { tumock-out results in reduced matrix adhesion and elevated migration [133] } \\
\text { - }\end{array}$ \\
\hline $\begin{array}{l}\text { COL1A2 } \\
\text { Type I collagen }\end{array}$ & $79.56(30.01)$ & $2.01(0.89)$ & $\begin{array}{l}\text { - Fibrillar collagen made up of two } \alpha 1(\mathrm{I}) \text { and one } \alpha 2(\mathrm{I}) \text { chain encoded by COL1A1 and COL1A2 } \\
\text { - Found everywhere in body, including skin, bone and other tissues [53] } \\
\text { - Provides mechanical stability and cellular integrity } \\
\text { - Fibronectin and different integrins attach to type I collagen } \\
\text { - TGF } \beta \text { induces transcription [25, 55] } \\
\text { - Over-expression seems to have tumor suppressive and anti-invasive function in glioma [53] }\end{array}$ \\
\hline $\begin{array}{l}\text { KRT18 } \\
\text { Keratin } 18\end{array}$ & $1.15(0.27)$ & $0.07(0.0058)$ & $\begin{array}{l}\text { - Type I keratin } \\
\text { - } \text { Belongs to simple epithelial keratins } \\
\text { - } \text { Highly conserved among different species }[114,115] \\
\text { - } \text { Protective function against mechanical and apoptosis } \\
\text { - Often expressed aberrantly in cancer }[16,77,97,116]\end{array}$ \\
\hline
\end{tabular}




\section{Discussion}

cDNA arrays were carried out to analyze the differences in gene expression patterns of normal and transformed RDEB-derived keratinocytes. The results indicate a prominent role of TGF $\beta$ signaling in the context of RDEB tumorigenesis. Hence, TGF $\beta$-related pathways and genes were examined more closely.

Keratinocytes, fibroblasts and cells of the immune system are main producers but also targets of TGF $\beta 1$ in the skin [41]. As this regulatory cytokine is able to influence many important processes in the cell, TGF $\beta 1$ and TGF $\beta$ signaling are worthwhile objects in the investigation of cancer development and progression.

TGF $\beta 1$ was found to be over-expressed in normal RDEB-CL keratinocytes (2.83 fold). This upregulation could be related to the different roles of TGF $\beta 1$. Lu et al. [75] showed that cells bordering a tumor also often exhibit elevated TGF $\beta 1$ levels. They assumed over-expression of TGF $\beta 1$ to be an early event in head and neck SCC development. Hence, overexpression of TGF $\beta 1$ in RDEB cells could mirror an early phase of tumor development. According to the assumed temporal role of TGF $\beta$ in cancer [59], it might also have anti-tumoral properties in RDEB-CL keratinocytes and could prevent their transformation into tumor cells.

Another aspect is TGF $\beta 1$ 's role in inflammatory and wound healing processes. It could be argued that elevated TGF $\beta 1$ levels in RDEB-CL could also be a result of these processes.

In the cancer cell line, SCCRDEB4, TGF 1 expression nearly doubles (4.91 fold) compared to RDEB-CL. It is feasible that TGF $\beta 1$ over-expression in the tumor cell line could be a sign for aggressive, highly metastasizing cancer.

\subsection{TGF $\beta$ signaling and the promotion of EMT}

TGF $\beta$ signaling is considered to be the main trigger for EMT (reviewed in [132]). A characteristic feature of this process is the down-regulation of cell adhesion molecules, e.g., E-cadherin [40]. In accordance, reduced E-cadherin expression has also been shown after prolonged exposure of early papillomas to TGF $\beta 1$ [131]. A study by Deng et al. [32] recently confirmed TGF $\beta 1$ as direct inducer of EMT. In contrast, real time RT-PCR results for CDHE mRNA revealed elevated levels of these transcripts (6.47 fold) in SCCRDEB4.
Also VCL, the protein coupling CDHE to the actin cytoskeleton, is up-regulated (6.95 fold).

These findings might be explained by the fact that the effects of TGF $\beta 1$ on E-cadherin expression are mediated not only by Smad4 through Snail and Slug induction [121] but also through Smad-independent signaling. Both mechanisms are needed for a full repression of E-cadherin expression [83]. Therefore it might be possible, that in SCCRDEB4 defects in Smad4 signaling and/or Snail inactivation could account for elevated CDHE mRNA levels.

Smad 4 knockdown has been shown to prevent CDHE down-regulation [121] and to suppress type I collagen synthesis [63]. As this reflects the situation present in our study, Smad 4 could be considered a possible candidate that might be defective in RDEB SCC.

The induction of Snail1 or Snail2 by TGF $\beta$ also results in E-cadherin suppression [9, 20] and elevated expression of FN [20, 96]. Therefore both, Snail1 and Snail 2 could be disturbed in SCCRDEB4. On the other hand, keratin 18 has been reported to be a direct target of Snail1: it mediates the down-regulation of keratin $18[29,45,58]$. Since we were able to show this downregulation in SCCRDEB4 (0.07; in contrast to 1.15 in RDEB-CL), defective Snail-related signaling appears to be less likely.

The helix-loop-helix transcription factors E12 and E47 are able to directly repress E-cadherin expression [99]. Beyond that, E47 is able to induce SPARC expression [86]. As SPARC in fact exhibits elevated mRNA levels in SCCRDEB4 (2.59 fold), it could be deduced that E47 defects seem to be unlikely as well.

Cells having acquired the mesenchymal phenotype after EMT show a different gene expression profile. An increase in ECM proteins (like collagens and FN) can be noticed, promoting cell migration by stimulation of integrin signaling and by induction of focal adhesion complexes (reviewed in [132]). By contrast, FN was found to be down-regulated in SCCRDEB4 (0.22 fold) in our study and these cells show only moderately elevated mRNA levels for COL1A2 (2.01 fold). Compared to untransformed RDEB keratinocytes, COL1A2 levels are even massively down-regulated as analysis of COL1A2 mRNA in RDEB-CL yielded a nearly 40fold over-expression (79.56 fold). Hence, there rather seems to be a down-regulation in type I collagen as compared to untransformed RDEB keratinocytes.

There are many pathways by which TGF $\beta$ signaling mediates the down-regulation of CDHE characteristic 
for EMT. As many of these function independently of each other, it seems to be highly unlikely that all these pathways are turned off or obstructed. Moreover, the results for other genes point out that some of these pathways seem to be working correctly.

Taken together, these findings argue for a preservation of the epithelial phenotype of SCCRDEB4 cells. As loss of CDHE is the hallmark for EMT, the only remaining conclusion is that obviously EMT has not (or not yet) taken place in SCCRDEB4, although elevated TGF $\beta 1$ levels would indicate that. Besides, an obstruction of CDHE expression is not sufficient to induce EMT [74] and neither does forced CDHE expression induce a restoration of the epithelial phenotype [92]. It remains to be investigated whether and how the genetic changes due to defects in type VII collagen could be responsible for this observation.

\subsection{TGF $\beta$ signaling in cell-cell contact, adhesion and migration}

Genes involved in changes of cell-cell contact, cellular adhesion and migratory potential, which are related to or influenced by TGF $\beta$ are TSP-1, COL7A1, FN and SPARC.

In many tumor types, TSP-1 is found to be downregulated [71]. Moreover, it appears that metastatic cells produce 3 -fold less TSP-1 than normal cells [90] and that decreased TSP-1 levels correlate with increased recurrence rates and decreased overall survival [44]. Many (but not all [21, 128]) SCCs have been shown to express only little amounts of TSP1 [18, 49]. Therefore, TSP-1 has been suggested as potent inhibitor of angiogenesis and tumor growth in skin carcinomas [120] and TSP-1 increasing drugs might be a promising strategy for cancer treatment in general [71]. We found this tumor suppressor gene to be down-regulated in SCCRDEB4 (0.14). A lack of TSP-1 might contribute to the aggressiveness of RDEB-related SCCs. Hence, the application of TSP-1 increasing anti-cancer drugs might prove useful.

In accordance with our results showing a strong decrease of FN mRNA levels in SCCRDEB4 (0.22 fold) despite elevated TGF $\beta 1$ expression, FN generally seems to be reduced in cancer cells [30]. Therefore, the decline in FN mRNA levels might not be due to some perturbation in TGF $\beta 1$ signaling, but might rather result from rapid decay of FN mRNA. However, more recent studies have implicated high levels of $\mathrm{FN}$ with tumor cell proliferation and low FN levels with dormant cancer cells [8]. Yet, all these results have been generated from studies using fibroblasts and not keratinocytes. It has already been shown that those two cell types react differently to the same signal(s) [123]. The role of FN mRNA repression in SCCRDEB4 keratinocytes is therefore difficult to interpret. A study by Berndt et al. in 1998 [11] on tissue samples of oral SCCs and breast cancer cells showed that these cells themselves synthesize only very small amounts of $\mathrm{FN}$ in vivo and that $\mathrm{FN}$ is produced mainly (if not exclusively) by stromal cells. Assuming that stromal cells like fibroblasts are the main source of FN, this might account for the reduced expression of this gene by SCCRDEB4 keratinocytes. On the other hand, RDEB-CL cells are also keratinocytes and they do not show a decrease in FN mRNA. Hence the loss of FN mRNA expression might very well provide for increased migratory potential of SCC cells.

Less information exists on the TGF $\beta$-mediated control over SPARC. It seems plausible, that TGF $\beta$ increases SPARC expression in order to influence processes like migration or proliferation [15]. In cancer, SPARC is often over-expressed [7, 80, 104, 111, 117]. These relations also seem to apply to SCCRDEB4 as we found increased TGF $\beta 1$ (4.91) and SPARC mRNA ( 2.59 fold) levels. Those might contribute to the migratory potential of RDEB SCC cancer cells. Elevated expression levels of SPARC indicate ongoing remodeling processes [15]. This way TGF $\beta$ signaling seems to increase cancer cell motility and could, in vivo, facilitate the development of metastasis.

TGF $\beta 1$ is also an enhancer of type VII collagen gene expression in keratinocytes and dermal fibroblasts [26, 91, 109]. In accordance, up-regulation of TGF $\beta 1$ in untransformed RDEB keratinocytes seems to increase COL7A1 mRNA levels (5.46 fold) although the present mutations would predict reduced levels of COL7A1 mRNA due to premature mRNA decay. This effect might be cell culture related. On the other hand Martins et al. [79] propose that loss of type VII collagen influences TGF $\beta 1$ signaling, leading to increased COL7A1 gene transcription. Although TGF $\beta 1$ levels are further elevated in SCCRDEB4, expression of COL7A1 mRNA drops to a very low level (0.29 fold). Reduction or absence of type VII collagen in RDEB keratinocytes has been reported to be related to increased migration and invasiveness [79], as well as enhanced motility and MMP expression [12, 24]. 
Hence the down-regulation of COL7A1 mRNA could to be related to the process of cancer development rather than TGF $\beta$ signaling. Other pathological processes could intercept the signal stimulating COL7A1 gene expression. TGF $\beta$ signaling seems to regulate the expression of a higher number of genes in transformed cells [101] and is hence able to influence more cellular processes and pathways in malignant cells. That way, expression of COL7A1 mRNA could be abolished.

\subsection{TGF $\beta$ signaling and MMP activity}

In tumors, TGF $\beta 1$ is able to induce the expression of MMP-2 and MMP-9 whilst simultaneously down-regulating their inhibitors, the TIMPs [40, 59]. Together these proteins contribute to migration and invasion of the tumor. MMPs are already known to be highly over-expressed in tumors $[3,14,22,28$, $42,48,95]$. This is also the case for SCCs in RDEB: Kivisaari et al. showed an up-regulation of MMP-7 and MMP-13 [66].

We are now able to demonstrate a dysregulation of their inhibitory molecule as well: while TIMP1 is expressed at elevated levels in RDEB-CL (2.61 fold), its expression is down regulated to normal levels in SCCRDEB4 (1.39 fold). Although there seems to be no reduction in TIMP1 expression as compared to normal keratinocytes, there clearly is a reduction of TIMP-1 levels in comparison to non-transformed RDEB cells. In SCCRDEB4, elevated levels of TGF $\beta 1$ seem to result in a down-regulation of TIMP-1. It can be suggested that RDEB-CL keratinocytes innately need higher levels of TIMP-1 to effectively control cell spreading. A reduction in TIMP-1 activity or a reduction of TIMP-1 mRNA to a normal level respectively, might therefore promote abnormal cell behavior and motility and hence favor SCC progression. MMPs might be less hindered from taking action now. As TIMPs bind to MMPs in 1:1 stoichiometry [52], elevated MMP levels and simultaneous down-regulation of TIMPs clearly indicates an imbalance between the two molecules and could result in or contribute to uncontrolled MMP activity.

Some of the genes mentioned in the context of cellcell contact, adhesion and migration are also involved in MMP synthesis, control or degradation.

TSP-1 is able to bind MMPs to facilitate their degradation via the LRP-1. Many carcinoma cell lines have been shown to produce only little or even no LRP1 [19]. LRP-1 already exhibits reduced levels in untransformed RDEB keratinocytes (0.26), while both TSP-1 (1.41) and TIMP-1 (2.61) expression is not altered or even elevated. This could also be interpreted as a factor that facilitates SCC development. SCCRDEB4 cells show reduced levels of TSP-1 (0.14) and LRP-1 (0.26) mRNA which might further contribute to uncontrolled activity of MMPs.

A down-regulation of type VII collagen has been associated with increased MMP expression as well $[12,24]$. The finding that type VII collagen shows reduced expression in SCCRDEB4 (0.29) might propose increased MMP expression in SCCRDEB4. This assumption is supported by the results of Kivisaari et al. [66].

SPARC increases the production [126] and stimulates the activation of various MMPs in different cell types [39, 64, 81, 119]. However, untransformed RDEB-CL keratinocytes show normal SPARC mRNA levels, despite TGF $\beta 1$ up-regulation indicating that TGF $\beta$ signaling still has an anti-tumor activity.

Obviously, there is not only a down-regulation of MMP-inhibitory molecules but also MMP degradation appears to be hindered. Additionally, TGF $\beta$ signaling appears to boost the expression and activation of MMPs. TGF $\beta 1$ seems to be a key player in MMP control in RDEB SCC. The ability of untransformed RDEB keratinocytes to degrade MMPs might already be weakened and it is possible that the up-regulation of TIMP-1 could result from or be meant to compensate this deficiency. Once TGF $\beta 1$ levels exceed a certain level and/or are put in a malignant context, this last line of defense against uncontrolled MMP activity could fail and promote tumor growth and metastasis. Hence TGF $\beta$ is likely to cause or contribute to the extraordinary aggressive behavior of SCCs in RDEB. Consequently, targeting this pathway might represent a useful supplementary strategy in cancer therapy of RDEB patients.

\subsection{TGF $\beta$ signaling and GPNMB}

Of certain interest is also the massive up-regulation of glycoprotein nonmetastatic B expression in SCCRDEB4 (144 fold). For some cancer types, GPNMB has already been proposed as possible tumor and/or prognostic marker [51, 108]. So, next to being a possible tumor marker for RDEB related 
SCC as well, GPNMB might also actively (although indirectly) take part in cancer promotion by further activating TGF $\beta 1$ through MMP activity. Besides, this GPNMB-mediated TGF $\beta 1$ activation could account for the increased TGF $\beta 1$ mRNA levels in the SCCRDEB4 as GPNMB expression is only elevated in the tumor cell line.

\section{Conclusion}

In conclusion, we have found clear indications that TGF $\beta$ signaling seems to be of general importance in RDEB as even untransformed RDEB keratinocytes show elevated levels of TGF $\beta 1$ mRNA. In a nonmalignant background this effect could be caused by wound healing processes or might act to elevate the expression of type VII collagen in order to counteract weakened cellular adhesion.

While TGF $\beta$-induced EMT apparently does not have a high relevance in RDEB related SCCs, its signaling appears to be of crucial importance in the control of MMP activity. Elevated TGF 1 mRNA levels in the tumor cell line SCCRDEB4 seem to provide for reduced MMP inhibition and degradation, while simultaneously promoting their expression and activation. Apart from MMP activity enhancement, TGF $\beta$ signaling is known to cause changes in cellular adhesion molecules that favor tumor spread and metastasis.

Importantly, the negative effect of elevated TGF $\beta$ expression can only be seen in SCCRDEB4. Hence, an over-expression of TGF $\beta 1$ itself does not seem to cause malignant consequences. Probably either a certain threshold of TGF $\beta 1$ has to be exceeded or additional mutations have to be acquired. Also the time period of exposure to TGF $\beta 1$ has been shown to be of vital importance [131]. Considering this, elevated TGF $\beta 1$ expression in RDEB-CL might represent a reason, why SCCs in RDEB preferentially develop on sites that are subject to constant wounding. TGF $\beta$ signaling is active in the context of wound healing, so body sites prone to blistering necessitate pronounced activity of this pathway. The prolonged exposure to TGF $\beta 1$ at elevated levels might promote SCC development and progression via the different actions described, especially by facilitating the loss of control over MMP activity. Targeting this signaling pathway might therefore contribute to RDEB cancer therapy. TGF $\beta 1$ becomes even more interesting as ele- vated expression and protein levels of this gene seem to be causative for the failure of tamoxifen treatment and tumor immunotherapy $[6,60]$.

\section{Acknowledgments}

The authors would like to thank Annemarie Frischauf and Fritz Aberger (Department of Molecular Biology, University of Salzburg) for their assistance in production of cDNA arrays. We also thank Debra International for providing the SCCRDEB4 and RDEB cell lines. This project was funded by the "Jubiläumsfonds der Österreichischen Nationalbank" (research grant No: 12689).

\section{References}

[1] F. Aberger, A.P. Costa-Pereira, J.F. Schlaak, T.M. Williams, R.F. O'Shaughnessy, G. Hollaus, I.M. Kerr and A.M. Frischauf, Analysis of gene expression using highdensity and IFN-gamma-specific low-density cDNA arrays, Genomics 77 (2001), 50-57.

[2] J.C. Adams and J. Lawler, Diverse mechanisms for cell attachment to platelet thrombospondin, J Cell Sci 104 (Pt 4) (1993), 1061-1071.

[3] K. Airola, N. Johansson, A.L. Kariniemi, V.M. Kahari and U.K. Saarialho-Kere, Human collagenase-3 is expressed in malignant squamous epithelium of the skin, J Invest Dermatol 109 (1997), 225-231.

[4] S.K. Akiyama, K. Olden and K.M. Yamada, Fibronectin and integrins in invasion and metastasis, Cancer Metastasis Rev 14 (1995), 173-189.

[5] B.K. Armstrong and A. Kricker, The epidemiology of UV induced skin cancer, J Photochem Photobiol B 63 (2001), $8-18$.

[6] C.L. Arteaga, K.M. Koli, T.C. Dugger and R. Clarke, Reversal of tamoxifen resistance of human breast carcinomas in vivo by neutralizing antibodies to transforming growth factor-beta, $J$ Natl Cancer Inst 91 (1999), 46-53.

[7] R.L. Aycock, A.C. Bradshaw, E.H. Sage and B. Starcher, Development of UV-induced squamous cell carcinomas is suppressed in the absence of SPARC, J Invest Dermatol 123 (2004), 592-599.

[8] D. Barkan, J.E. Green and A.F. Chambers, Extracellular matrix: A gatekeeper in the transition from dormancy to metastatic growth, Eur J Cancer 46 (2010), 1181-1188.

[9] E. Batlle, E. Sancho, C. Franci, D. Dominguez, M. Monfar, J. Baulida and A. Garcia De Herreros, The transcription factor snail is a repressor of E-cadherin gene expression in epithelial tumour cells, Nat Cell Biol 2 (2000), 84-89.

[10] K. Bein and M. Simons, Thrombospondin type 1 repeats interact with matrix metalloproteinase 2 . Regulation of metalloproteinase activity, J Biol Chem 275 (2000), 32167-32173.

[11] A. Berndt, L. Borsi, X. Luo, L. Zardi, D. Katenkamp and H. Kosmehl, Evidence of ED-B+fibronectin synthesis in human tissues by non-radioactive RNA in situ hybridiza- 
tion. Investigations on carcinoma (oral squamous cell and breast carcinoma), chronic inflammation (rheumatoid synovitis) and fibromatosis (Morbus Dupuytren), Histochem Cell Biol 109 (1998), 249-255.

[12] C. Bodemer, S.I. Tchen, S. Ghomrasseni, S. Seguier, F. Gaultier, S. Fraitag, Y. de Prost and G. Godeau, Skin expression of metalloproteinases and tissue inhibitor of metalloproteinases in sibling patients with recessive dystrophic epidermolysis and intrafamilial phenotypic variation, J Invest Dermatol 121 (2003), 273-279.

[13] P. Bornstein, Diversity of function is inherent in matricellular proteins: An appraisal of thrombospondin 1, J Cell Biol 130 (1995), 503-506.

[14] S.R. Bramhall, J.P. Neoptolemos, G.W. Stamp and N.R. Lemoine, Imbalance of expression of matrix metalloproteinases (MMPs) and tissue inhibitors of the matrix metalloproteinases (TIMPs) in human pancreatic carcinoma, J Pathol 182 (1997), 347-355.

[15] R.A. Brekken and E.H. Sage, SPARC, a matricellular protein: At the crossroads of cell-matrix, Matrix Biol 19 (2000), 569-580.

[16] H. Buhler and G. Schaller, Transfection of keratin 18 gene in human breast cancer cells causes induction of adhesion proteins and dramatic regression of malignancy in vitro and in vivo, Mol Cancer Res 3 (2005), 365-371.

[17] T. Burns, S. Breathnach, N. Cox and C. Griffith, ed., Rook's Textbook of dermatology, Oxford: Blackwell Science, 2004.

[18] B. Burnworth, S. Arendt, S. Muffler, V. Steinkraus, E.B. Brocker, C. Birek, W. Hartschuh, A. Jauch and P. Boukamp, The multi-step process of human skin carcinogenesis: A role for p53, cyclin D1, hTERT, p16, and TSP-1, Eur J Cell Biol 86 (2007), 763-780.

[19] C. Cabello-Verrugio and E. Brandan, A novel modulatory mechanism of transforming growth factor-beta signaling through decorin and LRP-1, J Biol Chem 282 (2007), 18842-18850.

[20] A. Cano, M.A. Perez-Moreno, I. Rodrigo, A. Locascio, M.J. Blanco, M.G. del Barrio, F. Portillo and M.A. Nieto, The transcription factor snail controls epithelial-mesenchymal transitions by repressing E-cadherin expression, Nat Cell Biol 2 (2000), 76-83.

[21] V. Castle, J. Varani, S. Fligiel, E.V. Prochownik and V. Dixit, Antisense-mediated reduction in thrombospondin reverses the malignant phenotype of a human squamous carcinoma, $J$ Clin Invest 87 (1991), 1883-1888.

[22] C.C. Chan, M. Menges, H.D. Orzechowski, N. Orendain, G. Pistorius, G. Feifel, M. Zeitz and A. Stallmach, Increased matrix metalloproteinase 2 concentration and transcript expression in advanced colorectal carcinomas, Int J Colorectal Dis 16 (2001), 133-140.

[23] L. Chandrasekaran, C.Z. He, H. Al-Barazi, H.C. Krutzsch, M.L. Iruela-Arispe and D.D. Roberts, Cell contact-dependent activation of alpha3beta1 integrin modulates endothelial cell responses to thrombospondin-1, Mol Biol Cell 11 (2000), 2885-2900.

[24] M. Chen, N. Kasahara, D.R. Keene, L. Chan, W.K. Hoeffler, D. Finlay, M. Barcova, P.M. Cannon, C. Mazurek and D.T. Woodley, Restoration of type VII collagen expression and function in dystrophic epidermolysis bullosa, Nat Genet 32 (2002), 670-675.

[25] S.J. Chen, H. Ning, W. Ishida, S. Sodin-Semrl, S. Takagawa, Y. Mori and J. Varga, The early-immediate gene EGR-1 is induced by transforming growth factor-beta and mediates stimulation of collagen gene expression, J Biol Chem $\mathbf{2 8 1}$ (2006), 21183-21197.

[26] Y.Q. Chen, A. Mauviel, J. Ryynanen, S. Sollberg and J. Uitto, Type VII collagen gene expression by human skin fibroblasts and keratinocytes in culture: Influence of donor age and cytokine responses, J Invest Dermatol 102 (1994), 205-209.

[27] A. Chlenski and S.L. Cohn, Modulation of matrix remodeling by SPARC in neoplastic progression, Semin Cell Dev Biol 21 (2010), 55-65.

[28] L. David, J.M. Nesland, R. Holm and M. Sobrinho-Simoes, Expression of laminin, collagen IV, fibronectin, and type IV collagenase in gastric carcinoma. An immunohistochemical study of 87 patients, Cancer 73 (1994), 518-527.

[29] B. De Craene, B. Gilbert, C. Stove, E. Bruyneel, F. van Roy and G. Berx, The transcription factor snail induces tumor cell invasion through modulation of the epithelial cell differentiation program, Cancer Res 65 (2005), 62376244.

[30] D.C. Dean, R.F. Newby and S. Bourgeois, Regulation of fibronectin biosynthesis by dexamethasone, transforming growth factor beta, and cAMP in human cell lines, $J$ Cell Biol 106 (1988), 2159-2170.

[31] K.A. Demali, Vinculin-a dynamic regulator of cell adhesion, Trends Biochem Sci 29 (2004), 565-567.

[32] B. Deng, X. Yang, J. Liu, F. He, Z. Zhu and C. Zhang, Focal adhesion kinase mediates TGF-beta1-induced renal tubular epithelial-to-mesenchymal transition in vitro, Mol Cell Biochem 340 (2010), 21-29.

[33] H. Emonard, G. Bellon, L. Troeberg, A. Berton, A. Robinet, P. Henriet, E. Marbaix, K. Kirkegaard, L. Patthy, Y. Eeckhout, H. Nagase, W. Hornebeck and P.J. Courtoy, Low density lipoprotein receptor-related protein mediates endocytic clearance of pro-MMP-2. TIMP-2 complex through a thrombospondin-independent mechanism, J Biol Chem 279 (2004), 54944-54951.

[34] R.M. Ezzell, W.H. Goldmann, N. Wang, N. Parashurama and D.E. Ingber, Vinculin promotes cell spreading by mechanically coupling integrins to the cytoskeleton, Exp Cell Res $\mathbf{2 3 1}$ (1997), 14-26.

[35] J.D. Fine, Inherited epidermolysis bullosa: Past, present, and future, Ann N Y Acad Sci 1194 (2010), 213-222.

[36] J.D. Fine, R.A. Eady, E.A. Bauer, J.W. Bauer, L. BrucknerTuderman, A. Heagerty, H. Hintner, A. Hovnanian, M.F. Jonkman, I. Leigh, J.A. McGrath, J.E. Mellerio, D.F. Murrell, H. Shimizu, J. Uitto, A. Vahlquist, D. Woodley and G. Zambruno, The classification of inherited epidermolysis bullosa (EB): Report of the third international consensus meeting on diagnosis and classification of EB, J Am Acad Dermatol 58 (2008), 931-950.

[37] J.D. Fine, L.B. Johnson, M. Weiner, K.P. Li and C. Suchindran, Epidermolysis bullosa and the risk of life-threatening cancers: The National EB Registry experience, 1986-2006, J Am Acad Dermatol 60 (2009), 203-211. 
[38] A. Francki, A.D. Bradshaw, J.A. Bassuk, C.C. Howe, W.G. Couser and E.H. Sage, SPARC regulates the expression of collagen type I and transforming growth factor-beta1 in mesangial cells, J Biol Chem 274 (1999), 32145-32152.

[39] C. Gilles, J.A. Bassuk, H. Pulyaeva, E.H. Sage, J.M. Foidart and E.W. Thompson, SPARC/osteonectin induces matrix metalloproteinase 2 activation in human breast cancer cell lines, Cancer Res 58 (1998), 5529-5536.

[40] A.B. Glick, TGFbeta1, back to the future: Revisiting its role as a transforming growth factor, Cancer Biol Ther 3 (2004), 276-283.

[41] A.B. Glick, R. Perez-Lorenzo and J. Mohammed, Contextdependent regulation of cutaneous immunological responses by TGFbeta1 and its role in skin carcinogenesis, Carcinogenesis 29 (2008), 9-14.

[42] G. Gonzalez-Avila, C. Iturria, F. Vadillo, L. Teran, M. Selman and R. Perez-Tamayo, 72-kD (MMP-2) and 92-kD (MMP9) type IV collagenase production and activity in different histologic types of lung cancer cells, Pathobiology 66 (1998), 5-16.

[43] M. Goodwin and A.S. Yap, Classical cadherin adhesion molecules: Coordinating cell adhesion, signaling and the cytoskeleton, J Mol Histol 35 (2004), 839-844.

[44] G.D. Grossfeld, D.A. Ginsberg, J.P. Stein, B.H. Bochner, D. Esrig, S. Groshen, M. Dunn, P.W. Nichols, C.R. Taylor, D.G. Skinner and R.J. Cote, Thrombospondin-1 expression in bladder cancer: Association with p53 alterations, tumor angiogenesis, and tumor progression, J Natl Cancer Inst 89 (1997), 219-227.

[45] S. Guaita, I. Puig, C. Franci, M. Garrido, D. Dominguez, E. Batlle, E. Sancho, S. Dedhar, A.G. De Herreros and J. Baulida, Snail induction of epithelial to mesenchymal transition in tumor cells is accompanied by MUC1 repression and ZEB1 expression, J Biol Chem 277 (2002), 39209-39216.

[46] E. Hahn-Dantona, J.F. Ruiz, P. Bornstein and D.K. Strickland, The low density lipoprotein receptor-related protein modulates levels of matrix metalloproteinase 9 (MMP-9) by mediating its cellular catabolism, J Biol Chem 276 (2001), 15498-15503.

[47] T. Hayakawa, K. Yamashita, K. Tanzawa, E. Uchijima and K. Iwata, Growth-promoting activity of tissue inhibitor of metalloproteinases-1 (TIMP-1) for a wide range of cells. A possible new growth factor in serum, FEBS Lett 298 (1992), 29-32.

[48] A. Hayasaka, N. Suzuki, N. Fujimoto, S. Iwama, E. Fukuyama, Y. Kanda and H. Saisho, Elevated plasma levels of matrix metalloproteinase-9 (92-kd type IV collagenase/gelatinase B) in hepatocellular carcinoma, Hepatology 24 (1996), 1058-1062.

[49] Y. Hayashido, M. Nakashima, K. Urabe, H. Yoshioka, Y. Yoshioka, T. Hamana, H. Kitano, K. Koizumi and T. Okamoto, Role of stromal thrombospondin-1 in motility and proteolytic activity of oral squamous cell carcinoma cells, Int J Mol Med 12 (2003), 447-452.

[50] J. Herz and D.K. Strickland, LRP: A multifunctional scavenger and signaling receptor, J Clin Invest 108 (2001), 779-784.

[51] T. Hoashi, S. Sato, Y. Yamaguchi, T. Passeron, K. Tamaki and V.J. Hearing, Glycoprotein nonmetastatic melanoma pro- tein $b$, a melanocytic cell marker, is a melanosome-specific and proteolytically released protein, FASEB J 24 (2010), 1616-1629.

[52] C.V. Hojilla, F.F. Mohammed and R. Khokha, Matrix metalloproteinases and their tissue inhibitors direct cell fate during cancer development, Br J Cancer 89 (2003), 1817-1821.

[53] K. Honma, T. Miyata, and T. Ochiya, Type. I collagen gene suppresses tumor growth and invasion of malignant human glioma cells, Cancer Cell Int 7 (2007), 12.

[54] A. Hovnanian, P. Duquesnoy, C. Blanchet-Bardon, R.G. Knowlton, S. Amselem, M. Lathrop, L. Dubertret, J. Uitto and M. Goossens, Genetic linkage of recessive dystrophic epidermolysis bullosa to the type VII collagen gene, J Clin Invest 90 (1992), 1032-1036.

[55] Y. Ichiki, E.A. Smith, E.C. LeRoy and M. Trojanowska, Basic fibroblast growth factor inhibits basal and transforming growth factor-beta induced collagen alpha 2(I) gene expression in scleroderma and normal fibroblasts, J Rheumatol $\mathbf{2 4}$ (1997), 90-95.

[56] R.A. Ignotz, T. Endo and J. Massague, Regulation of fibronectin and type I collagen mRNA levels by transforming growth factor-beta, J Biol Chem 262 (1987), 6443-6446.

[57] R.A. Ignotz and J. Massague, Transforming growth factorbeta stimulates the expression of fibronectin and collagen and their incorporation into the extracellular matrix, $J$ Biol Chem 261 (1986), 4337-4345.

[58] J. Ikenouchi, M. Matsuda, M. Furuse and S. Tsukita, Regulation of tight junctions during the epithelium-mesenchyme transition: Direct repression of the gene expression of claudins/occludin by Snail, J Cell Sci 116 (2003), 1959-1967.

[59] H. Ikushima and K. Miyazono, TGFbeta signalling: A complex web in cancer progression, Nat Rev Cancer 10 (2010), 415-424.

[60] P. Jachimczak, B. Hessdorfer, K. Fabel-Schulte, C. Wismeth, W. Brysch, K.H. Schlingensiepen, A. Bauer, A. Blesch and U. Bogdahn, Transforming growth factor-beta-mediated autocrine growth regulation of gliomas as detected with phosphorothioate antisense oligonucleotides, Int J Cancer 65 (1996), 332-337.

[61] B. Jimenez, O.V. Volpert, S.E. Crawford, M. Febbraio, R.L. Silverstein and N. Bouck, Signals leading to apoptosis-dependent inhibition of neovascularization by thrombospondin-1, Nat Med 6 (2000), 41-48.

[62] M.D. Johnson, H.R. Kim, L. Chesler, G. Tsao-Wu, N. Bouck and P.J. Polverini, Inhibition of angiogenesis by tissue inhibitor of metalloproteinase, J Cell Physiol 160 (1994), 194-202.

[63] A. Kaimori, J. Potter, J.Y. Kaimori, C. Wang, E. Mezey and A. Koteish, Transforming growth factor-betal induces an epithelial-to-mesenchymal transition state in mouse hepatocytes in vitro, J Biol Chem 282 (2007), 22089-22101.

[64] Y. Kato, J.M. Lewalle, Y. Baba, M. Tsukuda, N. Sakai, M. Baba, K. Kobayashi, S. Koshika, Y. Nagashima, F. Frankenne, A. Noel, J.M. Foidart and R.I. Hata, Induction of SPARC by VEGF in human vascular endothelial cells, Biochem Biophys Res Commun 287 (2001), 422-426.

[65] H. Kawasaki, D. Sawamura, F. Iwao, T. Kikuchi, H. Nakamura, S. Okubo, T. Matsumura and H. Shimizu, Squamous cell carcinoma developing in a 12 -year-old boy with 
nonHallopeau-Siemens recessive dystrophic epidermolysis bullosa, Br J Dermatol 148 (2003), 1047-1050.

[66] A.K. Kivisaari, M. Kallajoki, T. Mirtti, J.A. McGrath, J.W. Bauer, F. Weber, R. Konigova, D. Sawamura, K.C. Sato-Matsumura, H. Shimizu, M. Csikos, K. Sinemus, W. Beckert and V.M. Kahari, Transformation-specific matrix metalloproteinases (MMP)-7 and MMP-13 are expressed by tumour cells in epidermolysis bullosa-associated squamous cell carcinomas, Br J Dermatol 158 (2008), 778-785.

[67] M.D. Kosfeld and W.A. Frazier, Identification of active peptide sequences in the carboxyl-terminal cell binding domain of human thrombospondin-1, J Biol Chem 267 (1992), 16230-16236.

[68] H. Kosmehl, A. Berndt, S. Strassburger, L. Borsi, P. Rousselle, U. Mandel, P. Hyckel, L. Zardi and D. Katenkamp, Distribution of laminin and fibronectin isoforms in oral mucosa and oral squamous cell carcinoma, Br J Cancer $\mathbf{8 1}$ (1999), 1071-1079.

[69] M. Krieger and J. Herz, Structures and functions of multiligand lipoprotein receptors: Macrophage scavenger receptors and LDL receptor-related protein (LRP), Аппи Rev Biochem 63 (1994), 601-637.

[70] T.F. Lane and E.H. Sage, The biology of SPARC, a protein that modulates cell-matrix interactions, FASEB J 8 (1994), 163-173.

[71] J. Lawler and M. Detmar, Tumor progression: The effects of thrombospondin-1 and -2, Int J Biochem Cell Biol 36 (2004), 1038-1045.

[72] A.P. Lillis, I. Mikhailenko and D.K. Strickland, Beyond endocytosis: LRP function in cell migration, proliferation and vascular permeability, J Thromb Haemost 3 (2005), 1884-1893.

[73] A.P. Lillis, L.B. Van Duyn, J.E. Murphy-Ullrich and D.K. Strickland, LDL receptor-related protein 1: Unique tissuespecific functions revealed by selective gene knockout studies, Physiol Rev 88 (2008), 887-918.

[74] A. Llorens, I. Rodrigo, L. Lopez-Barcons, M. GonzalezGarrigues, E. Lozano, A. Vinyals, M. Quintanilla, A. Cano and A. Fabra, Down-regulation of E-cadherin in mouse skin carcinoma cells enhances a migratory and invasive phenotype linked to matrix metalloproteinase-9 gelatinase expression, Lab Invest 78 (1998), 1131-1142.

[75] S.L. Lu, D. Reh, A.G. Li, J. Woods, C.L. Corless, M. Kulesz-Martin and X.J. Wang, Overexpression of transforming growth factor beta1 in head and neck epithelia results in inflammation, angiogenesis, and epithelial hyperproliferation, Cancer Res 64 (2004), 4405-4410.

[76] R.A. Majack, S.C. Cook and P. Bornstein, Control of smooth muscle cell growth by components of the extracellular matrix: Autocrine role for thrombospondin, Proc Natl Acad Sci U S A 83 (1986), 9050-9054.

[77] T. Makino, M. Yamasaki, A. Takeno, M. Shirakawa, H. Miyata, S. Takiguchi, K. Nakajima, Y. Fujiwara, T. Nishida, N. Matsuura, M. Mori and Y. Doki, Cytokeratins 18 and 8 are poor prognostic markers in patients with squamous cell carcinoma of the oesophagus, Br J Cancer 101 (2009), 1298-1306.

[78] O.J. Marshall, PerlPrimer: Cross-platform, graphical primer design for standard, bisulphite and real-time PCR, Bioinformatics 20 (2004), 2471-2472.
[79] V.L. Martins, J.J. Vyas, M. Chen, K. Purdie, C.A. Mein, A.P. South, A. Storey, J.A. McGrath and E.A. O'Toole, Increased invasive behaviour in cutaneous squamous cell carcinoma with loss of basement-membrane type VII collagen, $J$ Cell Sci 122 (2009), 1788-1799.

[80] D. Massi, A. Franchi, L. Borgognoni, U.M. Reali and M. Santucci, Osteonectin expression correlates with clinical outcome in thin cutaneous malignant melanomas, Hum Pathol 30 (1999), 339-344.

[81] H.M. McClung, S.L. Thomas, P. Osenkowski, M. Toth, P. Menon, A. Raz, R. Fridman and S.A. Rempel, SPARC upregulates MT1-MMP expression, MMP-2 activation, and the secretion and cleavage of galectin-3 in U87MG glioma cells, Neurosci Lett 419 (2007), 172-177.

[82] J.A. McGrath, O.M. Schofield, B.J. Mayou, P.H. McKee and R.A. Eady, Epidermolysis bullosa complicated by squamous cell carcinoma: Report of 10 cases, J Cutan Pathol 19 (1992), 116-123.

[83] D. Medici, E.D. Hay and D.A. Goodenough, Cooperation between snail and LEF-1 transcription factors is essential for TGF-beta1-induced epithelial-mesenchymal transition, $\mathrm{Mol}$ Biol Cell 17 (2006), 1871-1879.

[84] I. Mikhailenko, M.Z. Kounnas and D.K. Strickland, Low density lipoprotein receptor-related protein/alpha 2-macroglobulin receptor mediates the cellular internalization and degradation of thrombospondin. A process facilitated by cell-surface proteoglycans, $J$ Biol Chem $\mathbf{2 7 0}$ (1995), 9543-9549.

[85] I. Mikhailenko, D. Krylov, K.M. Argraves, D.D. Roberts, G. Liau and D.K. Strickland, Cellular internalization and degradation of thrombospondin- 1 is mediated by the aminoterminal heparin binding domain (HBD). High affinity interaction of dimeric HBD with the low density lipoprotein receptor-related protein, J Biol Chem 272 (1997), 6784-6791.

[86] G. Moreno-Bueno, E. Cubillo, D. Sarrio, H. Peinado, S.M. Rodriguez-Pinilla, S. Villa, V. Bolos, M. Jorda, A. Fabra, F. Portillo, J. Palacios and A. Cano, Genetic profiling of epithelial cells expressing E-cadherin repressors reveals a distinct role for Snail, Slug, and E47 factors in epithelialmesenchymal transition, Cancer Res 66 (2006), 9543-9556.

[87] C. Moss, A. Wong and P. Davies, The Birmingham Epidermolysis and Bullosa, Severity score: Development and validation, Br J Dermatol 160 (2009), 1057-1065.

[88] K. Motegi, K. Harada, G. Ohe, S.J. Jones, I.R. Ellis, D.H. Crouch, S.L. Schor and A.M. Schor, Differential involvement of TGF-beta1 in mediating the motogenic effects of TSP-1 on endothelial cells, fibroblasts and oral tumour cells, Exp Cell Res 314 (2008), 2323-2333.

[89] J.E. Murphy-Ullrich and M. Poczatek, Activation of latent TGF-beta by thrombospondin-1: Mechanisms and physiology, Cytokine Growth Factor Rev 11 (2000), 59-69.

[90] M. Nacht, A.T. Ferguson, W. Zhang, J.M. Petroziello, B.P. Cook, Y.H. Gao, S. Maguire, D. Riley, G. Coppola, G.M. Landes, S.L. Madden and S. Sukumar, Combining serial analysis of gene expression and array technologies to identify genes differentially expressed in breast cancer, Cancer Res 59 (1999), 5464-5470.

[91] M. Naso, J. Uitto and J.F. Klement, Transcriptional control of the mouse Col7a1 gene in keratinocytes: Basal and trans- 
forming growth factor-beta regulated expression, $J$ Invest Dermatol 121 (2003), 1469-1478.

[92] P. Navarro, E. Lozano, and A. Cano, Expression of E- or P-cadherin is not sufficient to modify the morphology and the tumorigenic behavior of murine spindle carcinoma cells. Possible involvement of plakoglobin, J Cell Sci 105 (Pt 4) (1993), 923-934.

[93] C.M. Niessen and C.J. Gottardi, Molecular components of the adherens junction, Biochim Biophys Acta 1778 (2008), 562-571.

[94] T. Ogawa, T. Nikawa, H. Furochi, M. Kosyoji, K. Hirasaka, N. Suzue, K. Sairyo, S. Nakano, T. Yamaoka, M. Itakura, $\mathrm{K}$. Kishi and N. Yasui, Osteoactivin upregulates expression of MMP-3 and MMP-9 in fibroblasts infiltrated into denervated skeletal muscle in mice, Am J Physiol Cell Physiol 289 (2005), C697-C707.

[95] K. Ohashi, T. Nemoto, K. Nakamura and R. Nemori, Increased expression of matrix metalloproteinase 7 and 9 and membrane type 1-matrix metalloproteinase in esophageal squamous cell carcinomas, Cancer 88 (2000), 22012209.

[96] D. Olmeda, M. Jorda, H. Peinado, A. Fabra and A. Cano, Snail silencing effectively suppresses tumour growth and invasiveness, Oncogene 26 (2007), 1862-1874.

[97] R.G. Oshima, H. Baribault and C. Caulin, Oncogenic regulation and function of keratins 8 and 18, Cancer Metastasis Rev 15 (1996), 445-471.

[98] D.W. Owens and E.B. Lane, The quest for the function of simple epithelial keratins, Bioessays 25 (2003), 748-758.

[99] M.A. Perez-Moreno, A. Locascio, I. Rodrigo, G. Dhondt, F. Portillo, M.A. Nieto and A. Cano, A new role for E12/E47 in the repression of E-cadherin expression and epithelial-mesenchymal transitions, J Biol Chem 276 (2001), 27424-27431.

[100] S.H. Phan, R.G. Dillon, B.M. McGarry and V.M. Dixit, Stimulation of fibroblast proliferation by thrombospondin, Biochem Biophys Res Commun 163 (1989), 56-63.

[101] P. Ranganathan, A. Agrawal, R. Bhushan, A.K. Chavalmane, R.K. Kalathur, T. Takahashi, and P. Kondaiah, Expression profiling of genes regulated by TGF-beta: Differential regulation in normal and tumour cells, BMC Genomics 8 (2007), 98.

[102] A. Rattenholl, W.N. Pappano, M. Koch, D.R. Keene, K.E. Kadler, T. Sasaki, R. Timpl, R.E. Burgeson, D.S. Greenspan and L. Bruckner-Tuderman, Proteinases of the bone morphogenetic protein-1 family convert procollagen VII to mature anchoring fibril collagen, J Biol Chem 277 (2002), 26372-26378

[103] J.M. Ray, W.G. Stetler-Stevenson and Gelatinase, A activity directly modulates melanoma cell adhesion and spreading, EMBO J 14 (1995), 908-917.

[104] M.J. Reed and E.H. Sage, SPARC and the extracellular matrix: Implications for cancer and wound repair, Curr Top Microbiol Immunol 213 (Pt 1) (1996), 81-94.

[105] J.N. Rich, Q. Shi, M. Hjelmeland, T.J. Cummings, C.T. Kuan, D.D. Bigner, C.M. Counter and X.F. Wang, Bone-related genes expressed in advanced malignancies induce invasion and metastasis in a genetically defined human cancer model, J Biol Chem 278 (2003), 15951-15957.
[106] J.L. Rodriguez Fernandez, B. Geiger, D. Salomon, I. Sabanay, M. Zoller and A. Ben-Ze'ev, Suppression of tumorigenicity in transformed cells after transfection with vinculin cDNA, $J$ Cell Biol 119 (1992), 427-438.

[107] E. Roos, Cellular adhesion, invasion and metastasis, Biochim Biophys Acta 738 (1984), 263-284.

[108] A.A. Rose, A.A. Grosset, Z. Dong, C. Russo, P.A. Macdonald, N.R. Bertos, Y. St-Pierre, R. Simantov, M. Hallett, M. Park, L. Gaboury and P.M. Siegel, Glycoprotein nonmetastatic $\mathrm{B}$ is an independent prognostic indicator of recurrence and a novel therapeutic target in breast cancer, Clin Cancer Res 16 (2010), 2147-2156.

[109] J. Ryynanen, S. Sollberg, D.R. Olsen and J. Uitto, Transforming growth factor-beta up-regulates type VII collagen gene expression in normal and transformed epidermal keratinocytes in culture, Biochem Biophys Res Commun 180 (1991), 673-680.

[110] M. Ryynanen, J. Ryynanen, S. Sollberg, R.V. Iozzo, R.G. Knowlton and J. Uitto, Genetic linkage of type VII collagen (COL7A1) to dominant dystrophic epidermolysis bullosa in families with abnormal anchoring fibrils, $J$ Clin Invest 89 (1992), 974-980.

[111] N. Sakai, M. Baba, Y. Nagasima, Y. Kato, K. Hirai, K. Kondo, K. Kobayashi, M. Yoshida, S. Kaneko, T. Kishida, S. Kawakami, M. Hosaka, Y. Inayama and M. Yao, SPARC expression in primary human renal cell carcinoma: Upregulation of SPARC in sarcomatoid renal carcinoma, Hum Pathol 32 (2001), 1064-1070.

[112] I. Sargiannidou, J. Zhou and G.P. Tuszynski, The role of thrombospondin-1 in tumor progression, Exp Biol Med (Maywood) 226 (2001), 726-733.

[113] D. Sawamura, H. Nakano and Y. Matsuzaki, Overview of epidermolysis bullosa, J Dermatol 37 (2010), 214-219.

[114] M. Schaffeld, M. Haberkamp, E. Braziulis, B. Lieb and J. Markl, Type II keratin cDNAs from the rainbow trout: Implications for keratin evolution, Differentiation 70 (2002), 292-299.

[115] M. Schaffeld, S. Hoffling, M. Haberkamp, M. Conrad and J. Markl, Type I keratin cDNAs from the rainbow trout: Independent radiation of keratins in fish, Differentiation $\mathbf{7 0}$ (2002), 282-291.

[116] G. Schaller, I. Fuchs, W. Pritze, A. Ebert, H. Herbst, K. Pantel, H. Weitzel and E. Lengyel, Elevated keratin 18 protein expression indicates a favorable prognosis in patients with breast cancer, Clin Cancer Res 2 (1996), 1879_ 1885.

[117] C. Schultz, N. Lemke, S. Ge, W.A. Golembieski and S.A. Rempel, Secreted protein acidic and rich in cysteine promotes glioma invasion and delays tumor growth in vivo, Cancer Res 62 (2002), 6270-6277.

[118] J.E. Schwarzbauer, Alternative splicing of fibronectin: Three variants, three functions, Bioessays 13 (1991), 527-533.

[119] U.T. Shankavaram, D.L. DeWitt, S.E. Funk, E.H. Sage and L.M. Wahl, Regulation of human monocyte matrix metalloproteinases by SPARC, J Cell Physiol 173 (1997), 327-334.

[120] M. Streit, P. Velasco, L.F. Brown, M. Skobe, L. Richard, L. Riccardi, J. Lawler and M. Detmar, Overexpression of thrombospondin-1 decreases angiogenesis and inhibits the 
growth of human cutaneous squamous cell carcinomas, $A m$ J Pathol 155 (1999), 441-452.

[121] S. Takano, F. Kanai, A. Jazag, H. Ijichi, J. Yao, H. Ogawa, N. Enomoto, M. Omata and A. Nakao, Smad4 is essential for down-regulation of E-cadherin induced by TGF-beta in pancreatic cancer cell line PANC-1, J Biochem 141 (2007), 345-351.

[122] A. Takashima and F. Grinnell, Human keratinocyte adhesion and phagocytosis promoted by fibronectin, J Invest Dermatol 83 (1984), 352-358.

[123] H. Takeda, A. Kon, N. Ito, D. Sawamura, K. Takagaki, I. Hashimoto and K. Hanada, Keratinocyte-specific modulation of type VII collagen gene expression by pro-inflammatory cytokines (tumor necrosis factor-alpha and interleukin1beta), Exp Dermatol 14 (2005), 289-294.

[124] G. Taraboletti, D. Roberts, L.A. Liotta and R. Giavazzi, Platelet thrombospondin modulates endothelial cell adhesion, motility, and growth: A potential angiogenesis regulatory factor, J Cell Biol 111 (1990), 765-772.

[125] M. Tomihari, S.H. Hwang, J.S. Chung, P.D. Cruz Jr and K. Ariizumi, Gpnmb is a melanosome-associated glycoprotein that contributes to melanocyte/keratinocyte adhesion in a RGD-dependent fashion, Exp Dermatol 18 (2009), 586-595.

[126] P.M. Tremble, T.F. Lane, E.H. Sage and Z. Werb, SPARC, a secreted protein associated with morphogenesis and tissue remodeling, induces expression of metalloproteinases in fibroblasts through a novel extracellular matrix-dependent pathway, J Cell Biol 121 (1993), 1433-1444.

[127] J. Vandesompele, K. De Preter, F. Pattyn, B. Poppe, N. Van Roy, A. De Paepe and F. Speleman, Accurate normalization of real-time quantitative RT-PCR data by geometric averaging of multiple internal control genes, Genome Biol 3 (2002), RESEARCH0034.

[128] J. Varani, B.L. Riser, L.A. Hughes, T.E. Carey, S.E. Fligiel and V.M. Dixit, Characterization of thrombospondin synthesis, secretion and cell surface expression by human tumor cells, Clin Exp Metastasis 7 (1989), 265-276.

[129] S.A. Watt, C. Pourreyron, K. Purdie, C. Hogan, C.L. Cole, N. Foster, N. Pratt, J.C. Bourdon, V. Appleyard, K. Murray, A.M. Thompson, X. Mao, C. Mein, L. Bruckner-Tuderman, A. Evans, J.A. McGrath, C.M. Proby, J. Foerster, I.M. Leigh and A.P. South, Integrative mRNA profiling comparing cultured primary cells with clinical samples reveals PLK1 and $\mathrm{C} 20$ orf20 as therapeutic targets in cutaneous squamous cell carcinoma, Oncogene (2011), in press.

[130] F. Weber, J.W. Bauer, N. Sepp, W. Hogler, W. Salmhofer, H. Hintner and P. Fritsch, Squamous cell carcinoma in junctional and dystrophic epidermolysis bullosa, Acta Derm Venereol $\mathbf{8 1}$ (2001), 189-192.

[131] B.H. Weeks, W. He, K.L. Olson and X.J. Wang, Inducible expression of transforming growth factor beta1 in papillomas causes rapid metastasis, Cancer Res 61 (2001), 7435-7443.

[132] J. Xu, S. Lamouille and R. Derynck, TGF-beta-induced epithelial to mesenchymal transition, Cell Res 19 (2009), 156-172.

[133] W. Xu, H. Baribault and E.D. Adamson, Vinculin knockout results in heart and brain defects during embryonic development, Development 125 (1998), 327-337.

[134] T. Yagi and M. Takeichi, Cadherin superfamily genes: Functions, genomic organization, and neurologic diversity, Genes Dev 14 (2000), 1169-1180.

[135] K.M. Yamada, Cell surface interactions with extracellular materials, Anпи Rev Biochem 52 (1983), 761-799.

[136] Z. Yang, D.K. Strickland and P. Bornstein, Extracellular matrix metalloproteinase 2 levels are regulated by the low density lipoprotein-related scavenger receptor and thrombospondin 2, J Biol Chem 276 (2001), 8403-8408.

[137] W.H. Ziegler, R.C. Liddington and D.R. Critchley, The structure and regulation of vinculin, Trends Cell Biol 16 (2006), 453-460. 


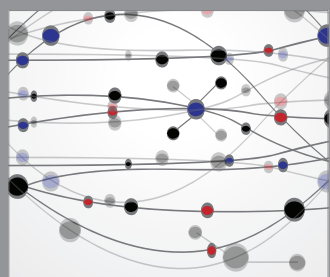

The Scientific World Journal
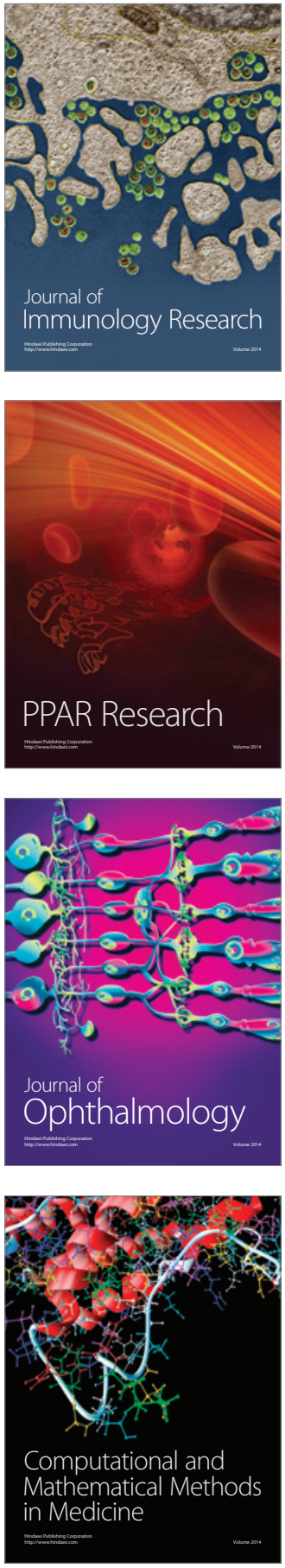

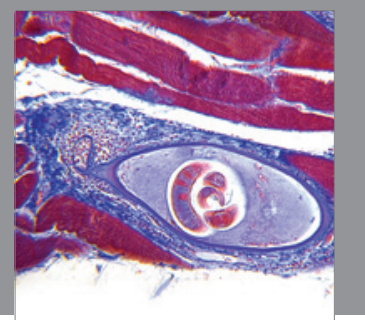

Gastroenterology

Research and Practice
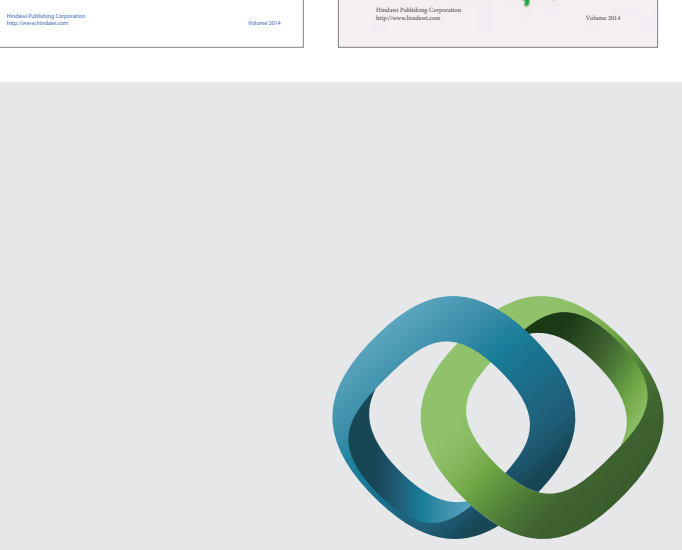

\section{Hindawi}

Submit your manuscripts at

http://www.hindawi.com
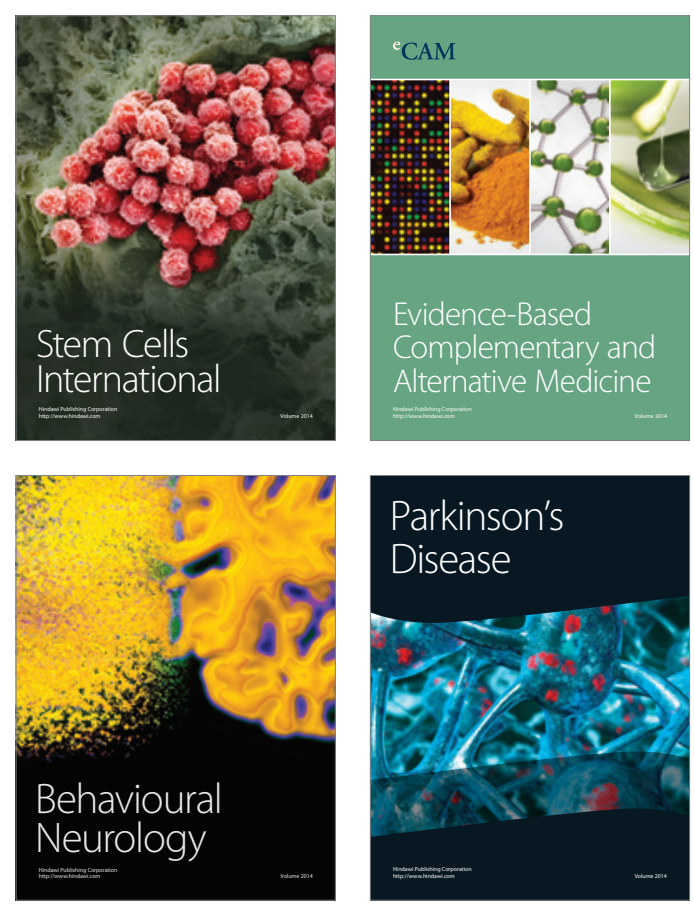

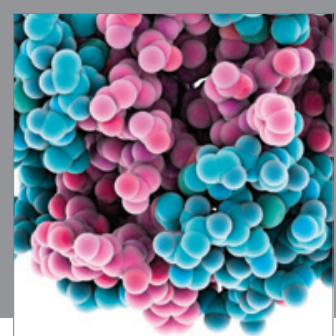

Journal of
Diabetes Research

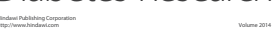

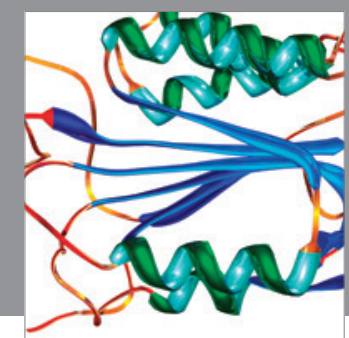

Disease Markers
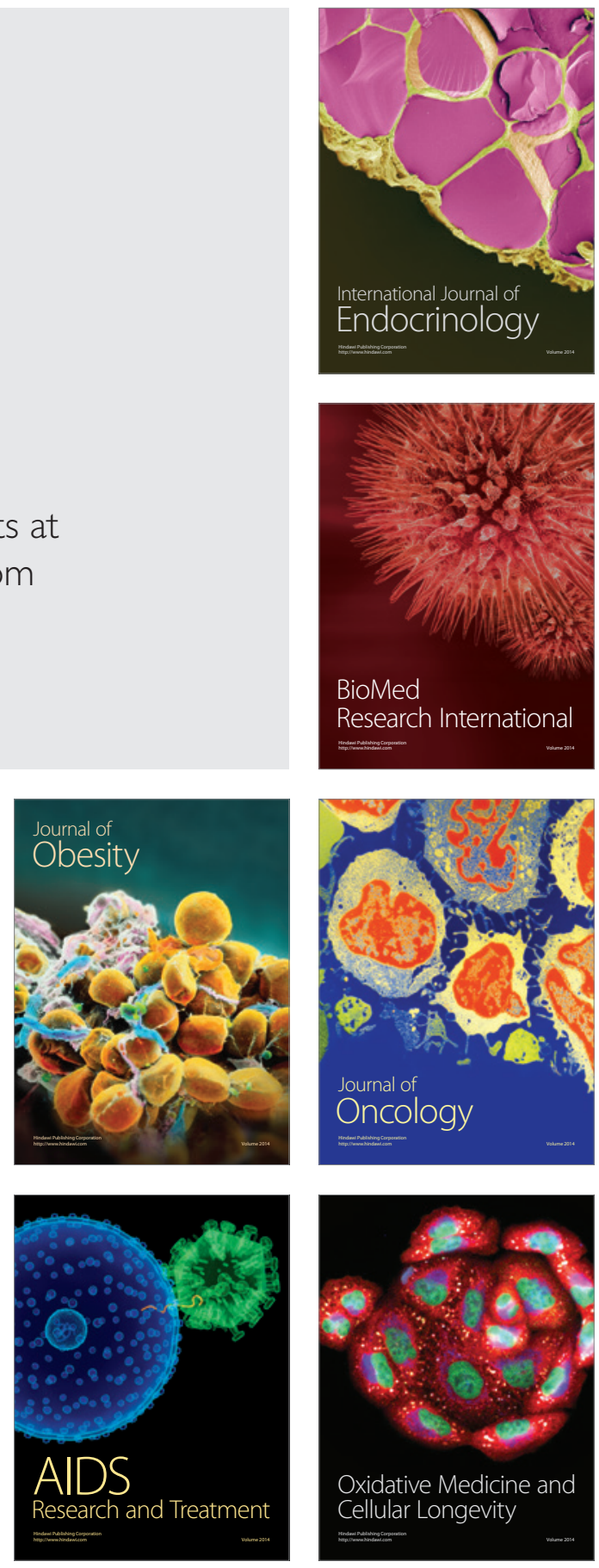